\title{
PENGEMBANGAN KOMPETENSI CREATIVE WRITING DALAM PEMBELAJARAN SASTRA DI PERGURUAN TINGGI
}

\author{
I.B. Putera Manuaba \\ Fakultas Ilmu Budaya Universitas Airlangga \\ email: putera_fib@unair.ac.id
}

\begin{abstract}
This study aims to identify creative writing aspects and formulate a model for the development of creative writing competence. It was a qualitative study involving literature students from four universities in Surabaya. The data were collected through in-depth interviews. The findings show that only few students have writing experience. The learning model in the campus is one important aspect that can motivate students to write. An ideal model for the development of creative writing competence is one that integrates a variety of aspects that can develop creative writing. Some important aspects include (1) a creative writing course in literature learning as a compulsory course at universities, (2) theory and practice (practice being more dominant than theory) for literature students, (3) attempts to make lecturers good at writing theory and practice, (4) reading enrichment in quality literary works, and (5) use of creative processes from high quality authors as inspiring part of creative work writing.
\end{abstract}

Keywords: creative writing identification, creative writing competence

\section{PENDAHULUAN}

Tradisi pembelajaran sastra di perguruan tinggi menunjukkan target kompetensi lulusan yang terbatas hanya menjadi analis sastra, ilmuwan sastra, atau kritikus sastra. Padahal, kompetensi lulusan yang juga diidealkan stakeholders adalah mampu sebagai pencipta karya sastra. Dalam pengamatan awal sebelum penelitian ini, diketahui kondisi mahasiswa sastra pada beberapa perguruan tinggi menunjukkan adanya minat yang cukup besar pada dunia penulisan kreatif.

Kondisi ini dapat dibuktikan dari banyaknya lulusan sastra yang secara otodidak menekuni penulisan kreatif; dan cukup banyak juga mahasiswa sastra yang sampai menulis di media massa dan menerbitkan buku sendiri. Berbagai publikasi yang menerbitkan karya-karya mereka tersebut ada yang terbit secara lokal ataupun nasional. Diketahui juga, para penulis mahasiswa sastra itu kebanyakan muncul dari komunitas yang mereka ikuti. Realitas menulis pada mahasiswa sastra yang tidak terdidik secara sistemik itu membuktikan bahwa, diakui atau tidak, kompetensi menulis kreatif telah menjadi kebutuhan bagi mahasiswa sastra.

Gairah dan antusiasme mahasiswa sastra menempuh pendidikan di perguruan tinggi justru karena ada image yang kuat tertanam bahwa setelah menempuh pendidikan di perguruan tinggi mampu menjadi penulis sastra. Image ini ditopang lagi dengan adanya teater kampus yang juga banyak memberikan peluang aktivitas penulis sastra.

Sementara itu, kenyataan empirik tentang pembelajaran penulisan kreatif di perguruan tinggi, menunjukkan kondisi dan tradisi yang tidak mendukung. 
Ini diakibatkan sebagian besar pengelola pembelajaran sastra di perguruan tinggi (PT) berpandangan bahwa PT bukan mengajari menulis sastra tetapi memberikan ilmu sastra agar nantinya menjadi ilmuwan sastra, analis sastra, atau kritikus sastra. Karena itu, kompetensi lebih tercurah pada tujuan tersebut.

Meski ada PT yang mencanangkan mata kuliah penulisan kreatif, namun mata ajaran ini dalam proses pembelajarannya masih dianggap bukan sebagai mata ajaran pokok tetapi hanya sebagai pelengkap. Jadi, secara umum, pembelajaran penulisan kreatif di PT selama ini belum mendapat penanganan khusus sebagai bagian dari proses pembelajaran sastra. Padahal, tradisi bersastra seharusnya termasuk meletakkan pentingnya aktivitas menulis kreatif. Sebab, kemampuan menulis sastra, bersinergi dengan aktivitas pembelajaran karya sastra.

Pandangan tersebut sebenarnya banyak didukung para pemikir kritik sastra, bahwa dalam pelaksanaan kritik sastra yang baik, idealnya adalah kritikus sastra sekaligus sebagai pengarang karya sastra. Artinya, dengan pengalaman sebagai pengarang sastra, kritikus akan mengetahui secara pasti proses kreatif lahirnya sebuah karya sastra yang akan dikritiknya.

Berangkat dari fenomena itu, khususnya yang berkembang dalam realitas empirik, ke depan cukup penting dikembangkan pembelajaran menulis kreatif yang profesional di perguruan tinggi. Dengan adanya pengarang yang terdidik secara akademis dan profesional di perguruan tinggi, pada masa yang akan datang perkembangan industri kreatif (creative industry) dapat berkembang pesat, dan tentu semakin banyak hasil pemikiran dan renungan yang terlahir dari para insan terdidik dengan dasar keilmuan sastra. Dengan menulis karya sastra, akan mampu dita- warkan nilai-nilai hidup yang bermanfaat bagi kemajuan masyarakat, bangsa, dan umat manusia.

Berkait dengan hal itu, dalam penelitian ini ada dua masalah pokok yang dikaji, yakni: bagaimanakah identifikasi creative writing mahasiswa sastra pada perguruan tinggi yang menyangkut motivasi, pengalaman, dan kemampuan menulis kreatif; dan bagaimanakah model pengembangan kompetensi creative writing yang bagaimana sajakah yang dapat diformulasikan untuk mendukung industri kreatif di Surabaya.

Pengembangan creative writing adalah suatu upaya membangkitkan potensi menulis sastra yang potensial ada pada mahasiswa sastra di berbagai PT. Pengembangan ini diperlukan karena selama ini konsentrasi pembelajaran sastra, khususnya di PT, terbatas berorientasi pada pembelajaran dan penguasaan ilmu sastra (teori sastra, kritik sastra, dan sejarah sastra); serta apresiasi, kajian, analisis, atau telaah atas karya sastra (genre puisi, prosa, dan teks drama). Padahal, menulis kreatif juga merupakan bagian pembelajaran sastra yang seharusnya menjadi bagian penting di perguruan tinggi. Namun, sampai saat ini, di kalangan ahli sastra di PT, aktivitas menulis karya sastra masih belum diposisikan sebagai bagian penting dalam aktivitas pembelajaran sastra. Dalam kenyataan, PT acapkali dianggap institusi pendidikan yang seharusnya mampu melahirkan penulis sastra yang baik. Pandangan tentang pentingnya penulisan kreatif di PT tentu saja perlu direspons dengan serius.

Atas dasar itulah dalam penelitian ini diidentifikasi dan sekaligus dikembangkan pembelajaran sastra, yang menyangkut creative writing di PT. Penelitian ini mengkaji bidang kajian sastra, khususnya pengembangan creative writing di PT. Penelitian seperti ini belum pernah dilakukan, namun ada 
penelitian-penelitian berkait yang dapat dideskripsikan di sini.

Pertama, pernah ada kajian tentang pembelajaran, namun menyangkut pembelajaran bahasa yang dilakukan oleh Surnyaman (2008), dalam penelitiannya berjudul "Pengembangan Model Buku Pelajaran Bahasa Indonesia Berbasis Pembelajaran Kontekstual" yang dituliskan pada terbitan Diksi: Jurnal Ilmiah Bahasa, Sastra, dan Pengajarannya. Kajian tersebut tidak berkait dengan sastra, namun dengan bahasa, yang dicoba dilakukan terhadap dosen dan mahasiswa.

Kedua, pernah ada penelitian tentang pembelajaran yang dilakukan oleh Sutarso (2007) berjudul "Model Pembelajaran Pendidikan Budi Pekerti Berbasis Budaya Lokal: Kasus Wayang Purwa", yang secara spesifik mengupas tentang peran wayang purwo dalam pembelajaran pendidikan budi pekerti. Penelitian ini lebih terkonsentrasi pada wayang purwo dalam kaitannya dengan perannya sebagai pembentuk budi pekerti di masyarakat.

Ketiga, pernah juga ada penelitian berjudul "Model Pembelajaran Berkehidupan Bersama Lintas Etnik dan Agama", yang dilakukan oleh M. Thoyibi (2007). Di dalam penelitian ini diangkat kajian tentang bagaimana kehidupan bersama dapat dibangun dalam masyarakat yang beragam baik dari segi etnis dan agama. Penelitian ini juga terbatas pada kajian hubungan sosial dalam masyarakat.

\section{METODE PENELITIAN}

Penelitian ini menggunakan model penelitian kualitatif (Moleong, 1990; Muhadjir, 1994). Digunakannya metode kualitatif karena dengan metode ini data dapat dijelaskan secara kualitatif. Dipilihnya jenis dan model penelitian ini karena disesuaikan dengan karakteristik objek penelitian yang menyangkut analisis pemahaman mahasiswa sastra tentang creative writing.

Unit analisis penelitian adalah mahasiswa sastra pada PT di Surabaya. Dalam penelitian ini mahasiswa sastra ditentukan dari empat perguruan tinggi (PT) sebagai objek, yang merupakan keterwakilan dari seluruh PT di Surabaya, yakni Universitas Negeri Surabaya (UNESA), Universitas Kristen Petra, Universitas Pendidikan Adi Buana (UNIPA), dan Universitas Airlangga (Unair). Dipilihnya empat PT ini karena memiliki fakultas yang mengajarkan sastra.

Data penelitian dikumpulkan dengan strategi wawancara (in-depth interview). Wawancara dilakukan terhadap informan yang berasal dari mahasiswa sastra pada perguruan tinggi di Surabaya. Digunakannya strategi ini karena cukup representatif untuk menggali informasi data yang ada pada mahasiswa sastra. Dari empat PT itu, dipilih informan mahasiswa sastra dengan jumlah yang representatif. Informasi dari informan itulah yang dipakai sebagai data penelitian ini.

Data penelitian dianalisis dengan cara analisis berikut. Pertama, mengidentifikasi pengalaman, motivasi, dan kemampuan mahasiswa sastra di PT dalam penulisan kreatif. Kedua, merumuskan model pengembangan creative writing di PT di Surabaya. Secara konkret, proses ini dapat dilihat pada bagan alir berikut.

Di dalam bagan alir tersebut dapat dilihat perihal penelitian ini dilaksanakan tahap demi tahap. Penelitian ini diawali dengan kajian yang terfokus pada identifikasi pengalaman, motivasi, dan kemampuan menulis kreatif mahasiswa sastra pada perguruan tinggi. Selanjutnya, pada kajian yang lebih terfokus pada perumusan model creative writing yang komprehensif dan aplikatif. 


\section{HASIL DAN PEMBAHASAN \\ Identifikasi Creative Writing pada Mahasiswa Sastra PT di Surabaya}

\begin{tabular}{|c|c|c|}
\hline $\begin{array}{c}\text { Merumuskan model } \\
\text { pengembangan kompetensi } \\
\text { creative writing }\end{array}$ & $\begin{array}{c}\text { Model pengembangan } \\
\text { kompetensi creative writing } \\
\text { pada mahasiswa perguruan } \\
\text { tinggi di Surabaya }\end{array}$ & $\begin{array}{c}\text { Dirumuskannya model } \\
\text { pengembangan creative } \\
\text { writing }\end{array}$ \\
\hline \multicolumn{3}{|l|}{4} \\
\hline $\begin{array}{l}\text { Identifikasi creative writing } \\
\text { mahasiswa sastra } \\
\text { menyangkut pengalaman, } \\
\text { motivasi dan kemampuan } \\
\text { menulis kreatif }\end{array}$ & $\begin{array}{l}\text { Hasil identifikasi creative } \\
\text { writing menyangkut } \\
\text { pengalaman, motivasi, dan } \\
\text { kemampuan menulis } \\
\text { kreatif }\end{array}$ & $\begin{array}{l}\text { Diperolehnya hasil iden- } \\
\text { tifikasi creative writing } \\
\text { menyangkut pengalam- } \\
\text { an, motivasi, kemam- } \\
\text { puan menulis kreatif }\end{array}$ \\
\hline PROSES PENELITIAN & LUARAN PENELITIAN & $\begin{array}{c}\text { INDIKATOR } \\
\text { CAPAIAN }\end{array}$ \\
\hline
\end{tabular}

Dalam mengidentifikasi creative writing pada mahasiswa sastra PT di Surabaya, ada tiga hal yang dilihat, yakni: pengalaman menulis kreatif, motivasi menulis kreatif, dan kemampuan menulis kreatif.

\section{Pengalaman Menulis Kreatif}

Dari proses identifikasi diketahui, mahasiswa sastra di Surabaya memiliki pengalaman menulis sastra kreatif yang masih rendah, mereka kebanyakan menyatakan belum pernah menulis sastra kreatif. Ada juga yang sudah mulai menulis, namun kebanyakan sekedar menulis atau untuk konsumsi sendiri. Adapun jenis karya yang paling banyak ditulis adalah puisi dan sedikit ada juga yang menulis prosa atau short stories, dan drama hampir kurang diminati untuk ditulis.

Menulis sastra kreatif ini kebanyakan mulai dilakukan mahasiswa sastra sejak menginjak dunia perguruan tinggi, ada yang dari semester dua, tujuh, dan sebagainya secara bervariasi. Ada juga sebagian kecilnya sudah me- nulis sejak umur lima tahun dan sejak SMA; khusus informan ini, agaknya ia memang memiliki bakat dari kecil untuk menulis. Melihat kenyataan ini, agaknya dunia perguruan tinggi tampak memberi inspirasi dalam menulis, walaupun mereka rasakan belum secara langsung dan optimal. Setidaknya, statusnya sebagai mahasiswa sastra membuat mereka sedikit tergerak untuk menulis, dan bahkan ada mahasiswa sastra yang menyebut langsung ketika ia memasuki mata kuliah creative writing: "ada 2 kelas yang mewajibkan untuk menulis karya sastra (intro to literature 1 dan creative writing)" (hasil wawancara). Mata ajaran tersebut diberikan sejak semester tujuh di Fakultas Sastra UK Petra.

Dari mahasiswa sastra yang menulis, diketahui juga bahwa karya-karya mereka belum banyak yang dipublikasikan. Namun itu bukan berarti sama sekali tidak ada. Ada karya-karya mereka yang dimuat dipamerkan dalam pameran Goethe (Goethe Exibition) dari mahasiswa sastra UK Petra (hasil wawancara), ada juga yang dimuat di majalah, ma- 
jalah dinding, dan ada juga yang telah menembus koran lokal seperti Surabaya Post, Jayabaya, dan Aksara, sebagaimana yang dilakukan mahasiswa sastra dari Fakultas Ilmu Budaya Universitas Airlangga (hasil wawancara).

Setelah karya kreatif mereka dimuat, kebanyakan menyatakan bahwa mereka sangat senang dan gembira, yang membuat mereka lebih terpacu atau termotivasi menulis. Seorang informan mahasiswa sastra dari Fakultas Sastra UK Petra juga merasa bangga jika karyanya dimuat, namun ia tidak hanya bangga tetapi juga senang jika karyakaryanya dibaca. Namun, ia tidak hanya asal senang karyanya dimuat. Ia bahkan sampai berpikir pada kualitas karya: "Tentu saja senang karena dibaca orang tapi lihat-lihat kualitasnya dulu. Kalau kualitasnya ok, no problem tapi kalau jelek ya mohon maaf, tambah malu jadinya." (hasil wawancara).

Mengenai jumlah karya yang dihasilkan, informan memang menjawab secara bervariasi. Ada yang tidak menyebut jumlahnya, ada yang menyebut dua buah, tujuh puluh dua, sepuluh buah, dan seterusnya. Bahkan ada juga yang menyatakan tidak ingat ia pernah menulis karya berapa jumlahnya.

Dari analisis terhadap identifikasi pengalaman menulis kreatif mahasiswa sastra tersebut, dapat diketahui bahwa memang pengalaman menulis pada mahasiswa sastra perguruan tinggi di Surabaya masih rendah. Namun, mahasiswa sastra sesungguhnya sangat berminat dalam menulis kreatif, terbukti misalnya jika karya mereka dimuat di ruang publik, mereka sangat bangga dan termotivasi menulis. Kenyataan ini patut direspons guna meningkatkan kuantitas dan kualitas menulis kreatif mereka. Minat, bakat, dan kebanggaan pada menulis kreatif sastra yang telah ada tersebut sebenarnya merupakan modal dasar untuk meningkatkan dan mengembangkan menulis kreatif di PT. Namun, kenyataan yang tampak adalah memang belum semua PT yang mengajarkan sastra memprogram mata kuliah creative writing, sehingga membuat minat, bakat, dan kebanggaan menulis kreatif tidak dapat berkembang baik di perguruan tinggi. Perguruan tinggi yang sudah memprogram mata kuliah penulisan kreatif, seperti di UK Petra, memang menjadi contoh yang baik jika kita berkomitmen dalam mengembangkan pembelajaran sastra yang lebih berkualitas.

\section{Motivasi Menulis Kreatif Sastra}

PT yang secara khusus melaksanakan pembelajaran sastra, bagi mahasiswa sastra dianggap sebenarnya memiliki peran yang sangat tinggi dalam membina dan mengembangkan kompetensi creative writing. Namun, selama ini, belum diketahui seberapa efektifkah PT memiliki kontribusi bagi pengembangan penulisan kreatif tersebut. Dalam penelitian ini diketahui sebagian besar Fakultas Sastra, Fakultas Bahasa dan Seni, atau Fakultas Ilmu Budaya sudah menawarkan mata ajaran creative writing.

Dari para informan yang memberikan informasinya, pada fakultas yang menawarkan mata ajaran ini, mahasiswa sastra memang rata-rata mengambil mata ajaran penulisan kreatif. Dari mereka yang mengambil mata ajaran tersebut, ada dua jawaban: 1) ada yang merasa termotivasi, dan 2) ada juga yang tidak termotivasi.

Selanjutnya, dari mereka yang merasa termotivasi, perlu dilihat lebih jauh, mengapa mereka merasa termotivasi dengan mengikuti mata ajaran tersebut. Seberapa jauh termotivasi dengan mata kuliah tersebut memang belum terungkap, mereka hanya menyatakan dapat memotivasi. Hal ini misalnya dapat dilihat dalam jawaban informan dari 
Fakultas Bahasa dan Seni Unesa berikut: "Ya, termotivasi. Khususnya karya sastra yang dibuat berdasarkan fakta atau pengalaman pribadi bisa lebih memotivasi untuk menghasilkan karya dengan 'jujur'"' (hasil wawancara). Ada juga yang termotivasi dalam hal penuangan ide dan mengajak orang berpikir (hasil wawancara) sebagaimana yang dialami mahasiswa sastra dari Fakultas Sastra Universitas Petra. Kemudian, informan lain, dari UK Petra, juga memberikan jawaban yang tegas bahwa pembelajaran creative writing memang dirasakannya sangat berguna: "Ya, sangat. Karena ingin tahu metode pembelajaran dosen dan ingin tahu teori menulis kreatif yang benar, tidak hanya asal menulis dengan subyektivitas yang ada." (hasil wawancara). Pentingnya pembelajaran creative writing di UK Petra ini menjadi pertanda baik bahwa mata ajaran ini sesungguhnya menduduki tempat yang sangat istimewa di mata mahasiswa sastra. Mungkin karena pengajar yang dilibatkan adalah yang berpengalaman, atau karena adanya seorang sastrawan sekaliber Budi Darma.

Namun dari data informan yang diperoleh ada juga yang memandang mata kuliah penulisan kreatif (creative writing) kurang memberi manfaat kepada mahasiswa sastra. Meskipun kemudian ia sendiri menulis sastra, namun ia tidak termotivasi dari mata ajaran penulisan kreatif yang diperolehnya, tetapi memang dari inisiatif mereka ikut dalam komunitas seni. Data informasi yang diperoleh dari Fakultas Ilmu Budaya Universitas Airlangga dikatakan: "Di kampus ada mata kuliah, penulisan kreatif. Ya saya mengambil. Motivasi saya bukan dari mata kuliah penulisan kreatif tapi sebelumnya dari teman-teman yang saya jumpai di komunitas Gapus, FS3LP, Tiwikromo" (hasil wawancara). Dari data tersebut perlu dilihat lebih jauh mengapa bukannya mata ajaran penulisan kreatif yang memotivasi penulisan kreatif ma- hasiswa sastra.

Perlu juga dilihat mengapa proses penulisan yang dilakukan mahasiswa sastra tumbuh dari komunitas yang diikutinya. Hal ini menjadi penting karena dengan tidak termotivasinya mahasiswa sastra dalam penulisan kreatif dari mata ajaran, perlu melihat proses pengajarannya: mengapa mata ajaran penulisan kreatif yang diperolehnya tidak memotivasi? Padahal, kalau disimak, pemberian mata ajaran itu dilakukan secara sistemik.

Ketika ditanyakan apa yang paling memotivasi dalam penulisan kreatif, sangat kecil jawaban yang mengatakan dari mata ajaran yang diberikan di perguruan tinggi Sebagian besar mengatakan di luar mata ajaran yang diberikan. Ada informan yang mengatakan: "komunitas Gapus, FS3LP, Tiwikromo" (hasil wawancara), "hobi dan pengalaman" (hasil wawancara), dan "teman-teman" (hasil wawancara). Namun, sebagian kecil ada juga yang menjawab bahwa mereka sangat termotivasi "sejak masuk kuliah" dan "ketika masuk kelas creative writing" (hasil wawancara).

Motivasi menulis kreatif ini kemudian dilihat juga dari pengaruh membaca sastra kreatif. Berdasarkan informasi yang diperoleh dari informan, dapat diungkapkan bahwa membaca sendiri sastra atau tulisan lainnya memang memotivasi untuk menulis. Informasi yang diperoleh dari informan mengatakan: "Saya suka membaca karya sastra dan menambah motivasi" (hasil wawancara), "Ya, termotivasi. Khususnya karya sastra yang dibuat berdasarkan fakta atau pengalaman pribadi bisa lebih memotivasi untuk menghasilkan karya dengan 'jujur'"' (hasil wawancara).

Ketika menanyakan kepada mahasiswa sastra soal keinginan awalnya, ada mahasiswa yang menjawab bahwa menjadi mahasiswa untuk menjadi pengarang atau penulis dan ada juga 
yang menjawab tidak menjadi pengarang atau penulis. Jawaban yang mereka berikan untuk jawaban ini kendatipun hampir imbang, namun mereka sejak awal memang membayangkan juga menjadi pengarang.

Harapan teman-teman atau keluarga informan ketika menempuh studi sebagai mahasiswa sastra, menurut informasi yang diberikan informan memang bervariasi. Ada yang mengatakan bahwa teman-temannya berharap: "Harapan teman-teman: dapat melanjutkan tradisi penulisan dan berestetika. Harapan saudara-saudara: kebanyakan mengira bahwa saya kelak akan menjadi guru bahasa Indonesia, namun keluarga dekat saya akhirnya mendukung/membebaskan saya." (hasil wawancara). Hal ini mungkin karena teman-temannya juga adalah penngarang. Di samping itu, ada juga jawaban bahwa teman-teman dan saudara-saudaranya yang biasa-biasa saja, ada juga yang tidak mengharapkan menjadi pengarang. Namun, dari anggapan pada umumnya ada harapan bahwa ketika informan masuk menjadi mahasiswa sastra juga memiliki profesionalitas sebagai pengarang.

Motivasi lain yang membuat informan tertarik menjadi penngarang, sebagian menjawab bahwa motivasinya dari diri sendiri dan kesadaran menjadi penngarang. Ada juga yang menjawab karena: didasari keinginan membuat drama, supaya tidak menjadi buruh, dan kompetisi atau lomba.

Ketertarikan dan motivasi menulis kreatif dalam dunia kampus, memang tidak bisa dilepaskan dari pengajarnya yang memiliki pengalaman dalam menulis kreatif. Jika bukan pengajar, mungkin dosen praktisi juga akan memberi daya tarik dan motivasi dalam menulis. Dari data riset diketahui bahwa para pengajar penulisan kreatif di perguruan tinggi, memang relatif masih belum memadai. Para mahasiswa sastra yang tertarik dengan penulisan kreatif menyatakan bahwa karena ada dosen yang memiliki profesionalitas menulis kreatif. Pada perguruan tinggi yang tidak diajarkan oleh dosen profesional, memang motivasinya sangat kurang. Atau, motivasi yang tumbuh pada mahasiswa sastra dalam menuliskan karya-karyanya bukan dari kuliah tetapi dari komunitas yang diikutinya. Kemungkinan di dalam komunitas itu ada teman-temannya dan tokoh profesional yang menginspirasi dirinya dalam menulis karya kreatif.

\section{Kemampuan Menulis Kreatif Sastra}

Satu hal yang sangat menentukan dalam menulis kreatif adalah jika memang memiliki kemampuan menulis. Kemampuan itu dapat diasah atau dibangun secara sistemik, khususnya di perguruan tinggi yang memberikan mata ajaran penulisan kreatif. Namun, kemampuan itu kemungkinan telah ada pada mahasiswa sastra.

Dari data penelitian diketahui bahwa bekal dan kemampuan menulis kreatif yang dimiliki mahasiswa sastra pada umumnya belum ada atau tidak ada. Mereka kebanyakan baru belajar, dan merasa baru mulai memiliki bekal ketika diajari oleh dosen pengajar yang profesional dalam menulis, misalnya "Profesor Budi Darma" (hasil wawancara). Ada juga informan yang mengatakan bahwa ia baru mulai bertekad memiliki bekal menulis: "Saya tidak mempunyai bekal banyak, saya harus berproses secara nekat" (hasil wawancara). Ada juga yang menjawab bahwa mata kuliah itu diperoleh setelah mengikuti kuliah: " $Y a$, karena selama masa kuliah banyak mata kuliah yang menunjang proses menulis karya kreatif." (hasil wawancara).

Dari informasi yang diberikan mahasiswa sastra dari perguruan tinggi di Surabaya tentang kemampuan yang selama ini dimiliki, mereka menjawab 
bahwa tidak banyak kemampuan yang dimiliki dalam menulis. Informan di antaranya mengatakan: "Saya tidak mempunyai kemampuan banyak, kemampuan proses saya mencari teknik/siapa tahu secara keberuntungan mendapatkan teknik baru. Yang saya butuhkan karya yang tidak wajar/berbeda" (hasil wawancara). Selanjutnya, ketika dimintai informasi tentang kemampuan yang dibutuhkan untuk menunjang menulis kreatif sastra, para informan menjawab dengan bervariasi; di antaranya ada yang menjawab: "Kemampuan menulis prosa dan puisi; kemampuan yang menunjang antara lain kemampuan memahami bahasa dan istilah (terminologi), penguasaan kata-kata, teknik menyusun karya sastra, dll." (hasil wawancara), "pemilihan bahasa, imajinasi" (hasil wawancara), "berpikir imajinatif, absurd, kemampuan membuat pembaca mengerti" (hasil wawancara). "Ide dan imajinasi, pengetahuan, filsafat, agama, gender, dll." (hasil wawancara).

Kemampuan menulis kreatif yang mereka peroleh itu, diperolehnya mahasiswa sastra dari sumber yang bervariasi pula, ada yang dari: kampus, komunitas, dan buku-buku. Dari informasi ini diketahui bahwa kampus memang belum menjadi sumber pemberian bekal menulis kreatif sastra. Mereka masih mencoba mencari dari luar (komunitaskomunitas) atau membaca buku-buku sendiri untuk menuliskan sastra.

Dengan adanya kondisi pemberian bekal menulis yang masih kurang seperti itu, berakibat pada kurangnya mahasiswa sastra memiliki bekal dan kemampuan menulis kreatif. Seluruh mahasiswa sastra mengatakan bahwa mereka kurang memiliki kemampuan menulis kreatif. Hal ini patut dicermati, bahwa di tengah cukup banyaknya mahasiswa sastra yang mengharapkan menjadi penngarang yang profesional, namun tidak didukung bekal menulis kreatif.
Oleh karena itu, pemberian bekal kemampuan menulis kreatif perlu ditingkatkan agar harapan para mahasiswa sastra menjadi pengarang sastra dapat terpenuhi. Pada dasarnya, mereka memiliki keinginan untuk meningkatkan kemampuan, khususnya yang dilakukan dalam proses pembelajaran menulis di kampus. Berikut adalah beberapa keinginan yang disampaikan oleh mahasiswa sastra untuk meningkatkan kemampuan menulis sastra: "lebih mengerti tata cara membuat hasil karya sastra", "pengetahuan sastra (tradisi-modern)", "diadakan kompetisi penulisan karya sastra", "memperbanyak koleksi sastra di perpustakaan", "sebuah media kampus", "ya berlatih terus dan menjadi produktif", dan "lebih banyak mata kuliah yang sifatnya output dan creati$v e^{\prime \prime}$ (hasil wawancara). Beberapa keinginan mahasiswa sastra itu penting artinya dalam meningkatkan pembelajaran penulisan kreatif. Untuk membangun tradisi menulis, diperlukan kemampuan tata cara menulis karya sastra, dan pengetahuan yang mendalam tentang sastra. Kompetisi menulis dalam lombalomba juga menjadi satu bagian yang turut meningkatkan penulisan kreatif. Untuk itu, perpustakaan yang mengoleksi sastra yang bagus juga akan sangat mendukung penulisan kreatif. Tidak hanya itu, tentu saja dibutuhkan latihan yang intensif, serta mata ajaran yang out put-nya adalah sastra.

Dengan adanya keinginan meningkatkan kemampuan menulis sastra pada mahasiswa, mata ajaran creative writing memiliki arti penting untuk mengembangkan penulisan kreatif. Dari data diketahui bahwa pembelajaran menulis kreatif dalam bentuk mata ajaran itu: "penting untuk membentuk jiwa sastra, jiwa enterpreuner, bukan yang terkekang konfensi tidak logis", "penting karena dapat memberikan motivasi dan panduan untuk mahasiswa yang ingin mengembangkan kemampuan penulisan khususnya di bidang 
sastra", "membantu mahasiswa mendalami ilmu sastra lebih lagi" (hasil wawancara).

Menyimak informasi yang diberikan oleh mahasiswa sastra, perguruan tinggi di Surabaya tidak hanya perlu memprogram mata ajaran tersebut, namun juga perlu meningkatkan kualitas pembelajarannya, sehingga dapat dikembangkan pembelajaran creative writing secara optimal. Implikasinya, mahasiswa sastra akan lebih termotivasi mengembangkan potensi dirinya dalam menulis kreatif.

\section{Model Pengembangan Kompetensi Creative Writing pada Mahasiswa Sastra}

Berdasarkan analisis atas identifikasi creative writing mahasiswa sastra di PT di Surabaya, diketahui bahwa mata ajaran creative writing perlu diajarkan di PT yang melaksanakan pembelajaran sastra. Diketahui juga mahasiswa sebagian besar sangat berharap mata ajaran creative writing tidak hanya menjadi mata ajaran pelengkap di PT yang menyelenggarakan pembelajaran sastra. Mata ajaran penulisan kreatif benar-benar dibutuhkan masyarakat umumnya dan mahasiswa sastra khususnya.

Bertitik-tolak dari pemahaman itu, model pengembangan kompetensi creative writing pada mahasiswa sastra di PT yang perlu dikembangkan adalah dengan model seperti berikut. Pertama, untuk model pengembangan ini creative writing perlu dijadikan sebagai mata ajaran wajib bagi mahasiswa sastra di PT. Dengan mata ajaran ini mahasiswa sastra nantinya memiliki keterampilan dan kemahiran dalam menulis kreatif. Bagaimanapun juga tradisi menulis memang perlu dibangun dari keseringan latihan menulis atau adanya tradisi menulis. Dalam pembelajaran sastra, selain ditekankan pada pembacaan dan pemahaman sastra, penting juga dilakukan penekanan pada penulisan sastra. Pe- ngalaman menulis, secara tidak langsung, sangat berpengaruh terhadap pemahaman dan penghayatan karya sastra.

Kedua, dalam model pengembangan penulisan kreatif, materi mata ajaran penulisan kreatif seyogianya mencakup perpaduan antara teori (pengetahuan) dan praktek (pengalaman) menulis. Dalam pelaksanaan pembelajaran menulis kreatif, mahasiswa tidak hanya diajak mengetahui dan memahami teori-teori menulis, tetapi juga langsung praktek dan melaksanakan menulis kreatif. Barangkali akan lebih baik, dalam pengembangan penulisan kreatif lebih dominan diorientasikan pada praktek menulis kreatif secara konkret.

Ketiga, untuk model pengembangan penulisan kreatif, dosen pengampu mata ajaran di samping diharuskan memiliki penguasaan teori-teori menulis juga harus adalah yang memiliki pengalaman menulis sastra. Semakin berpengalaman dosen pengampu, semakin ideallah proses pembelajaran tersebut. Jika memang tidak ada dosen yang berpengalaman dalam mengajarkan penulisan kreatif, maka dapat meminta dosen outshourcing antar perguruan tinggi.

Keempat, dalam pengembangan menulis kreatif pada mahasiswa sastra PT, mahasiswa sastra perlu membaca karya-karya sastra terbaik guna mempelajari keunggulan karya, dan untuk selanjutnya dapat diterapkan dalam aktivitas kepenulisan kreatifnya. Dalam hal ini, diyakini bahwa semakin kaya pembacaan atas sastra terbaik (baik yang berbahasa Indonesia maupun asing), berimplikasi pada peningkatkan kualitas sastra yang diciptakan mahasiswa sastra. Dengan bacaan yang luas, mahasiswa sastra semakin mengasah kemampuan menulisnya, sehingga akan dapat menghasilkan sastra yang berkualitas. 
Kelima, dalam upaya membangun model pengembangan creative writing, belajar dari proses kreatif pengarang juga menjadi hal yang inspiratif bagi penulisan kreatif. Dalam hal ini, mahasiswa sastra bukan diajak meniru proses kreatifnya, tetapi lebih menggunakan proses kreatif para pengarang sebagai inspirator agar mahasiswa sastra dapat melejitkan potensi dirinya dalam menulis karya kreatif sastra sesuai dengan jati dirinya sebagai pengarang sastra.

Selanjutnya, model pengembangan kompetensi creative writing tersebut, dapat dikonkretkan dalam skema yang memperlihatkan model pengembangan berikut.

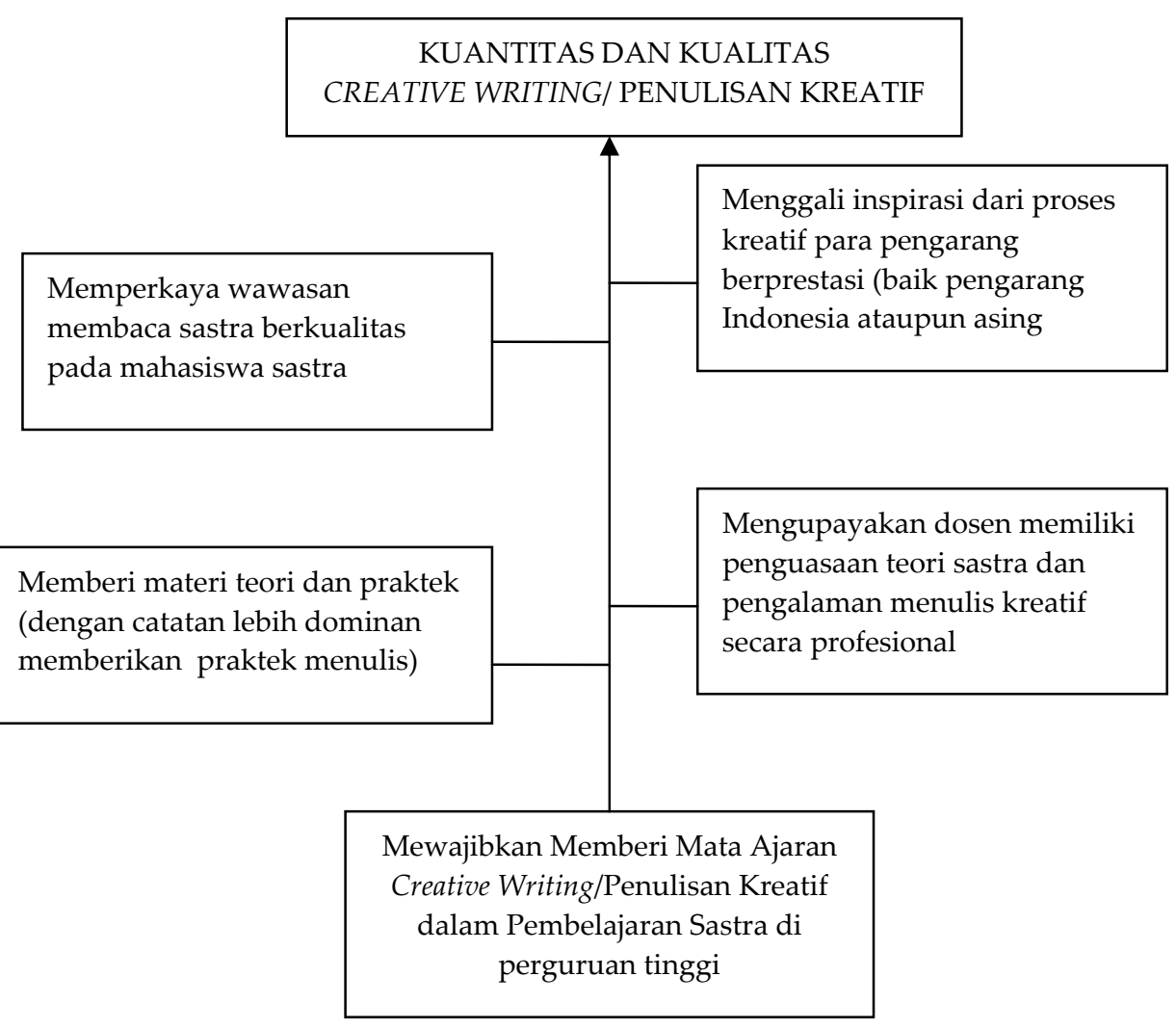

\section{Bagan Pengembangan Creative Writing}

\section{SIMPULAN}

Pertama, setelah dilakukan identifikasi creative writing pada mahasiswa sastra PT diketahui bahwa mahasiswa sastra memang ada yang memiliki pengalaman dan tidak memiliki pengalaman menulis. Namun, secara domi- nan, mahasiswa sastra memang kurang memiliki pengalaman menulis. Dari identifikasi motivasi menulis mahasiswa sastra, diketahui mereka memang termotivasi dengan motif yang bervariasi, namun pembelajaran di kampus memang potensial memotivasi, hanya 
saja belum tampak menonjol. Dari kemampuan menulis mahasiswa sastra diketahui bahwa mereka merasa belum memiliki kemampuan yang cukup sehingga berimplikasi pada produktivitas karya yang dihasilkan. Mereka yang memiliki kemampuan lebih tinggi tampak lebih produktif. Kemampuan yang dimiliki selama ini banyak digali dari upaya mahasiswa sastra belajar secara otodidak dan belum pada pembelajaran yang sistemik. Namun, sekaligus juga mereka mengakui dan bahkan berharap bahwa pembelajaran sastra di kampus sangat membuka peluang bagi pengembangan penulisan kreatif. Hanya saja perlu dikembangkan secara optimal, seperti dengan menyiapkan pengajar yang profesional, penonjolan pada praktek, penyediaan referensi menulis kreatif, dan sebagainya.

Kedua, model pengembangan creative writing pada mahasiswa sastra perguruan tinggi yang diidealkan adalah model yang terintegrasi secara simultan antarberbagai hal yang secara langsung ataupun tidak langsung dapat mengembangkan kompetensi creative writing. Beberapa hal yang dimaksudkan di sini adalah: 1) mewajibkan mata ajaran creative writing dalam pembelajaran sastra di perguruan tinggi, 2) membekali mahasiswa sastra dengan teori dan praktek (dengan lebih dominan praktek menulis), 3) mengupayakan dosen memiliki penguasaan teori dan pengalaman menulis, 4) memperkaya membaca sastra berkualitas, dan 5) menggunakan proses kreatif pengarang berkualitas sebagai bagian yang menginspirasi dalam menulis kreatif.

\section{UCAPAN TERIMA KASIH}

Ucapan terima kasih disampaikan kepada para mahasiswa fakultas sastra dari empat perguruan tinggi (PT) di Surabaya, yakni Universitas Negeri
Surabaya (UNESA), Universitas Kristen Petra, Universitas Pendidikan Adi Buana (UNIPA), dan Universitas Airlangga (Unair) yang telah membantu pelaksanaan penelitian. Selanjutnya ucapan terima kasih disampaikan kepada rekan sejawat yang telah membantu kegiatan verifikasi dan triangulasi data dan interpertasi, serta kepada reviewer anonim yang telah membaca, mengoreksi dan memberi masukan terhadap artikel ini.

\section{DAFTAR PUSTAKA}

Moleong, Lexy J. 1990. Metode Penelitian Kualitatif. Bandung: Rosda Karya.

Muhadjir, Noeng H. 1994. Metodologi Penelitian Kualitatif. Yogyakarta: Yake Sarasin

Nasir, Moch. 1985. Metode Penelitian. Yogyakarta: Ghalia Indonesia.

Suryaman, Maman. 2008. "Pengembangan Model Buku Pelajaran Bahasa Indonesia Berbasis Pembelajaran Kontekstual", dalam Diksi: Jurnal Ilmiah Bahasa, Sastra, dan Pengajarannya, Vol. 15 No.1 Januari.

Sutarso, Joko. 2007. "ModelPembelajaran Pendidikan Budi Pekerti Berbasis Budaya Lokal: Kasus Wayang Purwo." Laporan Hasil Penelitian DP2M Ditjen Dikti di Universitas Muhammadiyah Surakarta.

Thoyibi, M. 2007. "Model Pembelajaran Berkehidupan Bersama Lintas Etnik dan Agama". Laporan Hasil Penelitian Hibah Bersaing DP2M Ditjen Dikti di Universitas Muhammadiyah Surakarta.

Widianingsih, Nunung Sri. 2008. “Menuntun Kreativitas Siswa dalam Menulis Puisi". Horison, Tahun XLII, No.4/2008, April, halaman 15 